\title{
Preparedness and vulnerability of African countries against introductions of 2019-nCoV
}

Marius Gilbert ${ }^{1,2, *}$, Giulia Pullano ${ }^{3,4}$, Francesco Pinotti $^{3}$, Eugenio Valdano ${ }^{5}$, Chiara Poletto $^{3}$, Pierre-Yves Boëlle ${ }^{3}$, Eric D’Ortenzio ${ }^{6,7}$, Yazdan Yazdanpanah ${ }^{6,7}$, Serge Paul

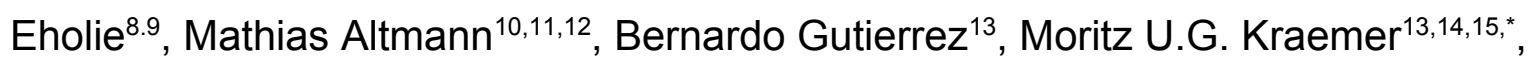
Vittoria Colizza ${ }^{3}$

1 Spatial Epidemiology Lab (SpELL), Université Libre de Bruxelles, Brussels, Belgium 2 Fonds National de la Recherche Scientifiques, Brussels, Belgium 3 INSERM, Sorbonne Université, Institut Pierre Louis d'Epidémiologie et de Santé Publique, IPLESP, Paris, France

4 Sociology and Economics of Networks and Services lab at Orange Experience Design Lab (SENSE/XDLab) Chatillion, Paris, France

5 Center for Biomedical Modeling, The Semel Institute for Neuroscience and Human Behavior, David Geffen School of Medicine, University of California Los Angeles, Los Angeles, United

States

6 Université de Paris, IAME, INSERM, F-75018 Paris, France

7 Bichat Claude Bernard Hospital, APHP, Paris France

8 Service des Maladies Infectieuses et Tropicales, Centre Hospitalier Universitaire de Treichville, Abidjan, Côte d'Ivoire

9 Département de Dermatologie-Infectiologie, Unité de Formation et de Recherche des Sciences Médicales, Université Félix Houphouet-Boigny, Abidjan, Côte d'Ivoire 10 IDLIC - Maladies infectieuses dans les pays à ressources limitées, Bordeaux, France 11 ISPED - Institut de Santé Publique et d'Épidémiologie du Développement, Bordeaux, France 12 Bordeaux Population Health, Inserm U1219, Bordeaux, France

13 Department of Zoology, University of Oxford, Oxford, UK

14 Harvard Medical School, Harvard University, Boston, United States

15 Computational Epidemiology Group, Boston Children's Hospital, Boston, United States

*equal contribution

Correspondence should be addressed to: Vittoria Colizza, vittoria.colizza@inserm.fr 
medRxiv preprint doi: https://doi.org/10.1101/2020.02.05.20020792; this version posted February 7, 2020. The copyright holder for this preprint (which was not certified by peer review) is the author/funder, who has granted medRxiv a license to display the preprint in perpetuity.

It is made available under a CC-BY-ND 4.0 International license .

\section{Abstract}

Background. The novel coronavirus (2019-nCoV) epidemic has spread to 23 countries from China. Local cycles of transmission already occurred in 7 countries following case importation. No African country has reported cases yet. The management and control of 2019-nCoV introductions heavily relies on country's health capacity. Here we evaluate the preparedness and vulnerability of African countries against their risk of importation of 2019-nCoV.

Methods. We used data on air travel volumes departing from airports in the infected provinces in China and directed to Africa to estimate the risk of introduction per country. We determined the country's capacity to detect and respond to cases with two indicators: preparedness, using the WHO International Health Regulation Monitoring and Evaluation Framework; and vulnerability, with the Infectious Disease Vulnerability Index. Countries were clustered according to the Chinese regions contributing the most to their risk.

Findings. Countries at the highest importation risk (Egypt, Algeria, Republic of South Africa) have moderate to high capacity to respond to outbreaks. Countries at moderate risk (Nigeria, Ethiopia, Sudan, Angola, Tanzania, Ghana, Kenya) have variable capacity and high vulnerability. Three clusters of countries are identified that share the same exposure to the risk originating from the provinces of Guangdong, Fujian, and Beijing, respectively.

Interpretation. Several countries in Africa are stepping up their preparedness to detect and cope with 2019-nCoV importations. Resources and intensified surveillance and capacity capacity should be urgently prioritized towards countries at moderate risk that may be ill-prepared to face the importation and to limit onward transmission.

Funding. This study was partially supported by the ANR project DATAREDUX (ANR-19-CE46-0008-03) to VC; the EU grant MOOD (H2020-874850) to MG, CP, MK, PYB, VC. 
medRxiv preprint doi: https://doi.org/10.1101/2020.02.05.20020792; this version posted February 7, 2020. The copyright holder for this preprint (which was not certified by peer review) is the author/funder, who has granted medRxiv a license to display the preprint in perpetuity.

It is made available under a CC-BY-ND 4.0 International license .

\section{Introduction}

On January 30, 2020, the World Health Organization (WHO) declared the current novel coronavirus (2019-nCoV) epidemic a Public Health Emergency of International Concern [1]. As of February 1, the epidemic registered 11,818 cases in China and spread to 23 countries that reported a total of 127 cases [2]. Limited local transmission outside China has been reported in Germany, France, Japan, South Korea, Thailand, Vietnam, and the United States.

All continents reported confirmed cases of 2019-nCoV, except Africa. China, however, is the leading commercial partner for Africa, and this generates large travel volumes through which the novel coronavirus might eventually reach the continent. Several measures have already been put in place to prevent and control possible case importations from China $[3,4]$.

The ability to limit and control local transmission following introduction depends, however, on the application and execution of strict measures of detection, prevention and control. These include heightened surveillance, rapid identification of suspect cases followed by patient transfer and isolation, rapid diagnosis, tracing and follow-up of potential contacts [1]. The application of such a vast technical and operational set of interventions depends on countries' public health and laboratory infrastructures and resources.

Here we assessed the risk of importation to Africa of 2019-nCoV cases from affected provinces in China and put it in relation with countries' vulnerability to epidemic emergencies and capacity to respond. Importation risk is determined by the volumes of the air traffic connections [5-9] from areas where the virus currently circulates in China. Countries' functional capacity to manage health security issues is based on WHO International Health Regulation (IHR) Monitoring and Evaluation Framework (MEF) [10], and on an indicator of vulnerability to emerging epidemics.

\section{Methods}

The risk of importation of 2019-nCoV cases to Africa from China was estimated based on origin-destination air-travel flows from January 2019 [8,11,12], number of cases in Chinese provinces, and the population in each of the Chinese provinces that report transmission. Case data were compiled as part of an international effort to build a database at individual level, and included all confirmed cases recorded until the 27th January 2020 [13]. Human population data per province [14] was used to estimate incidence in China. Province-level incidence data were linked to the three airports with the largest volumes in each province [12] (Fig. 1). The province of Hubei was not included among the possible locations that can export the virus, given the 
travel ban put in place by Chinese authorities on January 23rd and 24th [5]. The importation risk per country in Africa measured the probability of importing a case from the infected provinces in China, accounting for the origin-destination travel flows originated from such provinces and for their different epidemic levels (see appendix for details).

For each African country, the most likely origins of the potential case importation were identified. This was done by computing a country's exposure to each Chinese province, measuring the probability for a city in China to be the origin of a travelling case to the country. Similarity between exposure profiles of different countries was quantified with entropy-based metrics [15], and used to group countries with similar importation patterns via agglomerative clustering (see appendix for details).

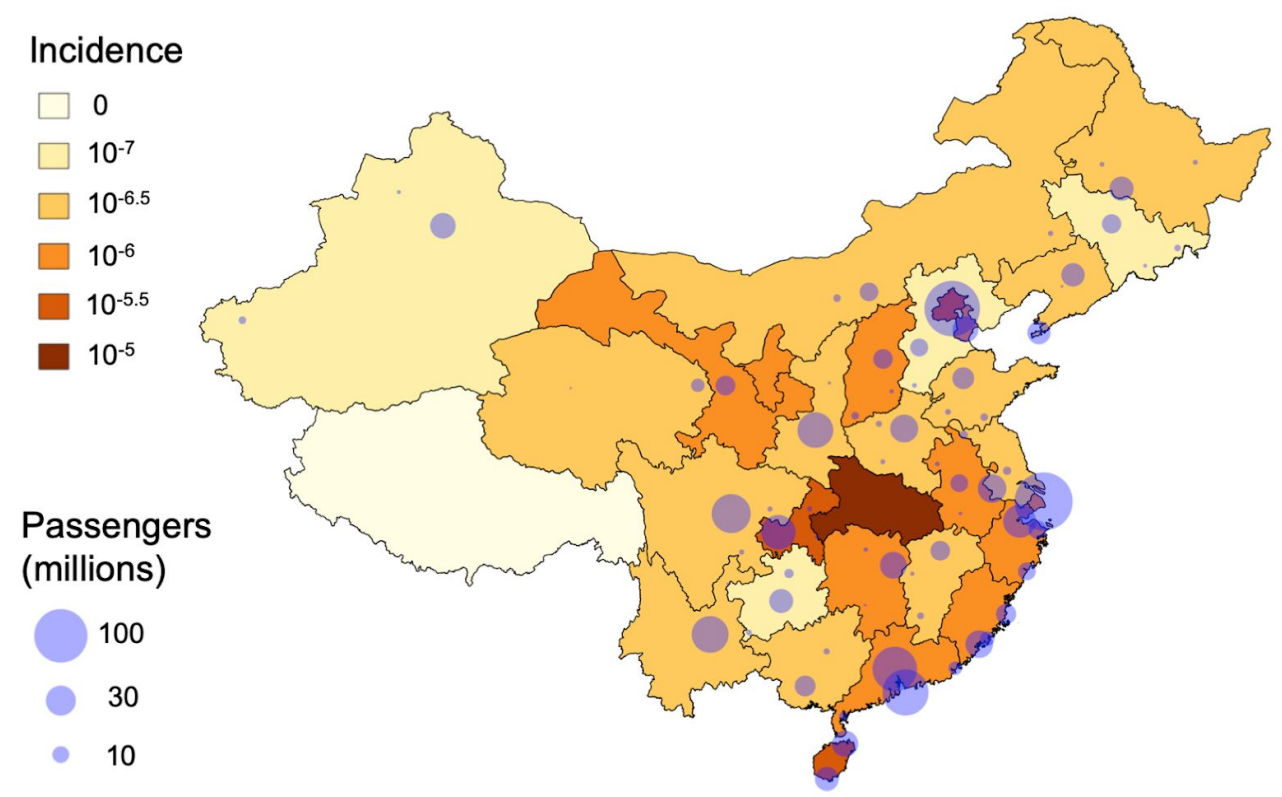

Figure 1 2019-nCoV incidence in China as of 27th January 2020 [13] and annual volume of outflow passenger per airport [12].

Indicators of capacity were taken from the WHO International Health Regulation (IHR) Monitoring and Evaluation Framework (MEF), a set of four components developed by WHO in consultation with partners to support the evaluation of countries' functional ability to manage health security issues. The MEF is composed of a mandatory self-reporting of capacity (the State Parties self-assessment Annual Reporting, SPAR [10]), and three voluntary components, 
medRxiv preprint doi: https://doi.org/10.1101/2020.02.05.20020792; this version posted February 7, 2020. The copyright holder for this preprint (which was not certified by peer review) is the author/funder, who has granted medRxiv a license to display the preprint in perpetuity.

It is made available under a CC-BY-ND 4.0 International license .

namely the Joint External Evaluation (JEE), the after-action reviews (AAR) and simulation exercises (SimEx) (all collected and disseminated by WHO).

The 2018 SPAR database [16] contained a total of 20 indicator scores on a scale of 0 to 100 , organized and grouped according to the following capacities (number between brackets is the number of indicators per capacity, see [10]): Legislation (2), IHR Coordination (2), Zoonoses (1), Food safety (1), Laboratory (3), Surveillance (2), Human resource (1), National health emergency framework (3), Health service provision (3), Communication (1), Points of Entry (2), Chemical events (1) and Radiation emergency (1). From them, we derived two aggregated indicators that would be relevant to quantify the countries capacity to deal with the introduction and spread of 2019-nCoV. The first quantifies the overall capacity of a country to deal with an emergency linked to a directly transmitted infectious disease, from early detection to the overall handling of a potential epidemic, and was estimated as an average between all indicators, except those of the groups Zoonoses, Food safety, Chemical events, Radiation emergency. The second was more focused on early detection, and averaged the scores of the groups Laboratory, Surveillance, Points of Entry. A very high correlation between the two metrics was found (All countries: $r=0.929, n=182, p<0.001$; Africa : $r=0.893, n=52, p<0.001$ ), so we considered only the first metric that we call SPAR indicator in the following analyses.

The vulnerability of countries to epidemic risk is measured with the Infectious Disease Vulnerability Index (IDVI) that was introduced as a synthetic metric to account for a broader set of factors, including descriptors of health care, public health, economic, demographic, disease dynamics, and political (domestic and international) conditions [17]. While the SPAR indicator is a self-evaluation of countries capacity focusing on public health, the IDVI indicator includes broader sets of conditions that may have an impact on the management of a disease emergency.

Both SPAR and IDVI indicators range from 0 to 100, with increasing levels of capacity and decreasing vulnerability.

\section{Results}

Egypt, Algeria and South Africa were the top three countries at highest introduction risk, with moderate to high SPAR capacity scores (87, 76 and 62 , respectively) and IDVI $(53,49,69)$ (Figure 2). Following countries in the introduction risk ranking include Nigeria and Ethiopia with moderate capacity $(51,67$, respectively), but high vulnerability $(27,38)$ and substantially larger 
populations potentially exposed (Figure 3). Morocco, Sudan, Angola, Tanzania, Ghana and Kenya have similar moderate importation risk and population sizes. However, these countries present variable levels of capacity (ranging from 34 to 75$)$ and an overall low IDVI (<46) reflecting a high vulnerability (except Morocco, with IDVI equal to 56). All other countries had low to moderate importation risk and low to moderate IDVI, with a majority having relatively low SPAR capacity score, with the exception of Tunisia and Rwanda.

Three clusters were identified among the countries with non-negligible risk (Figure 4). Each of the clusters corresponds to different Chinese airports as main source of entry risk (pie charts of Figure 4). The red cluster is highly exposed to Beijing province, moderately exposed to Guangdong and Shanghai provinces. The green cluster (including Botswana and Lesotho only) is exposed exclusively to the potential risk from airports in the Fujian province, and the blue cluster is heavily exposed to risk from Guangdong province and weakly to Zhejiang province.
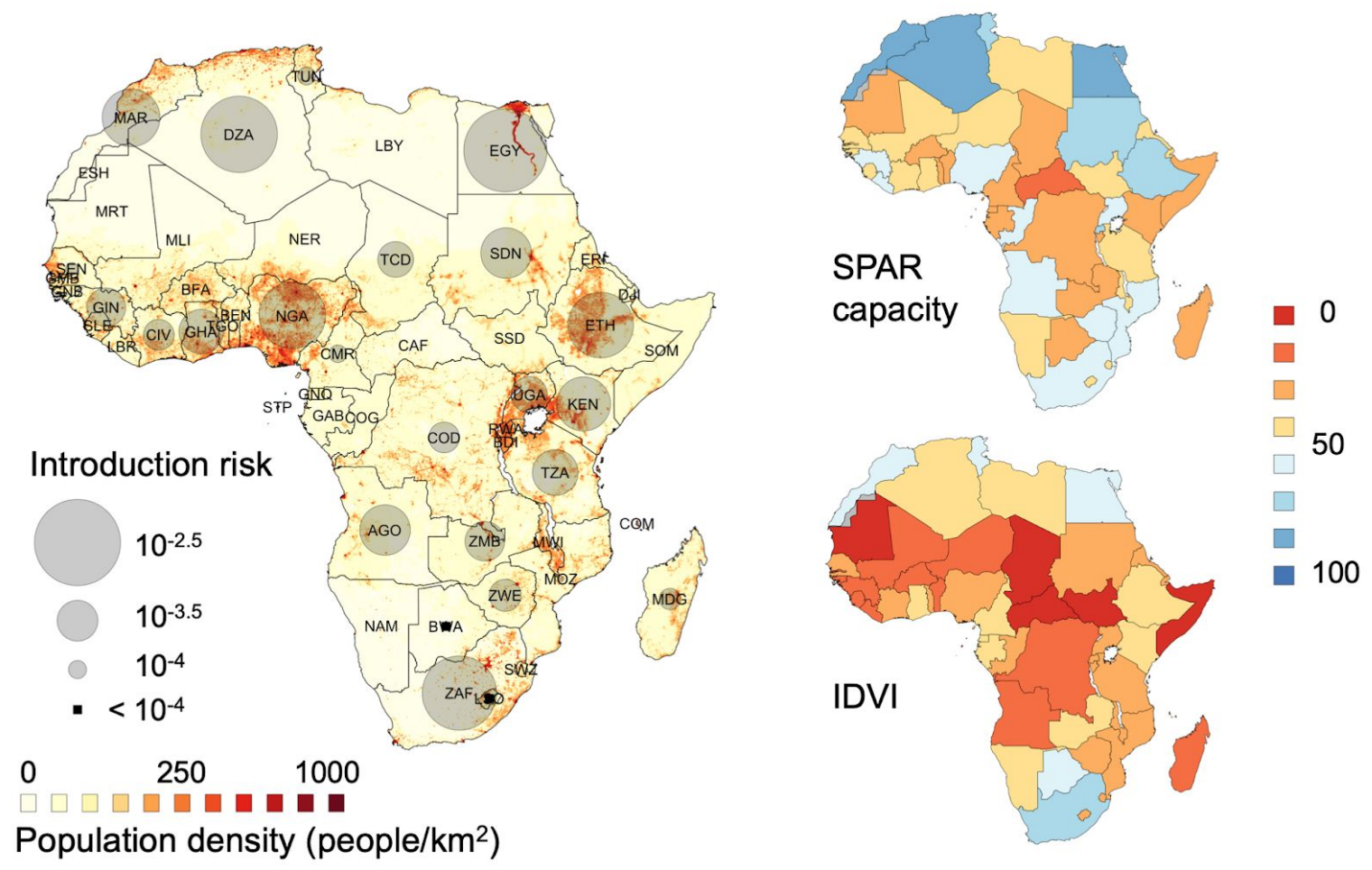

Figure 2 Global distribution of introduction risk over human population density (left) and distribution of the SPAR capacity index (top right) and Infectious Disease Vulnerability Index (IDVI, bottom right). Countries with no estimates of introduction risk correspond to situations where the risk of entry was found to be negligible at the time of analysis. 
medRxiv preprint doi: https://doi.org/10.1101/2020.02.05.20020792; this version posted February 7, 2020. The copyright holder for this preprint (which was not certified by peer review) is the author/funder, who has granted medRxiv a license to display the preprint in perpetuity.

It is made available under a CC-BY-ND 4.0 International license .
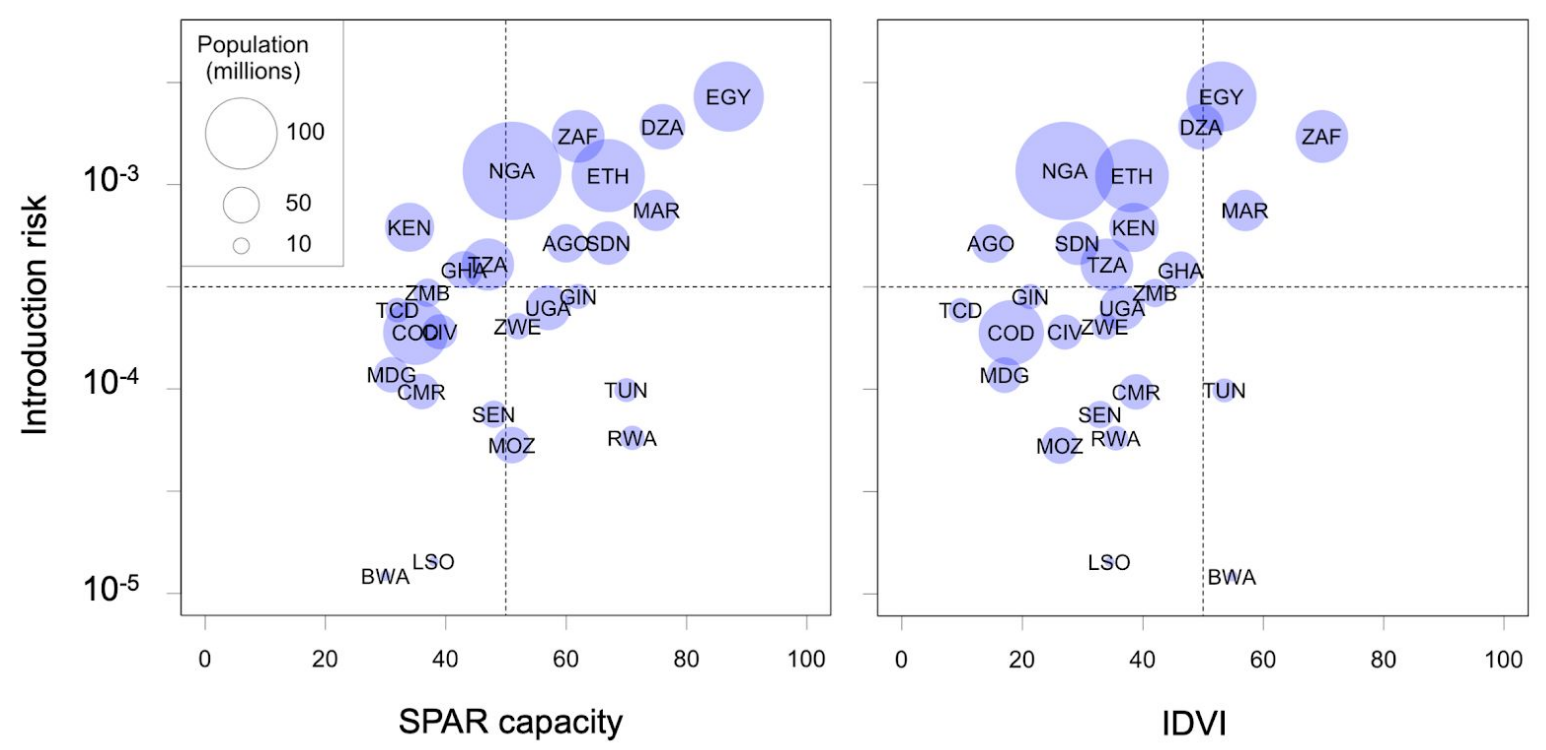

Figure 3 Introduction risk as a function of the SPAR capacity index (left) and Infectious Disease Vulnerability Index (IDVI, right) in Africa. Area of circles is proportional to country population.

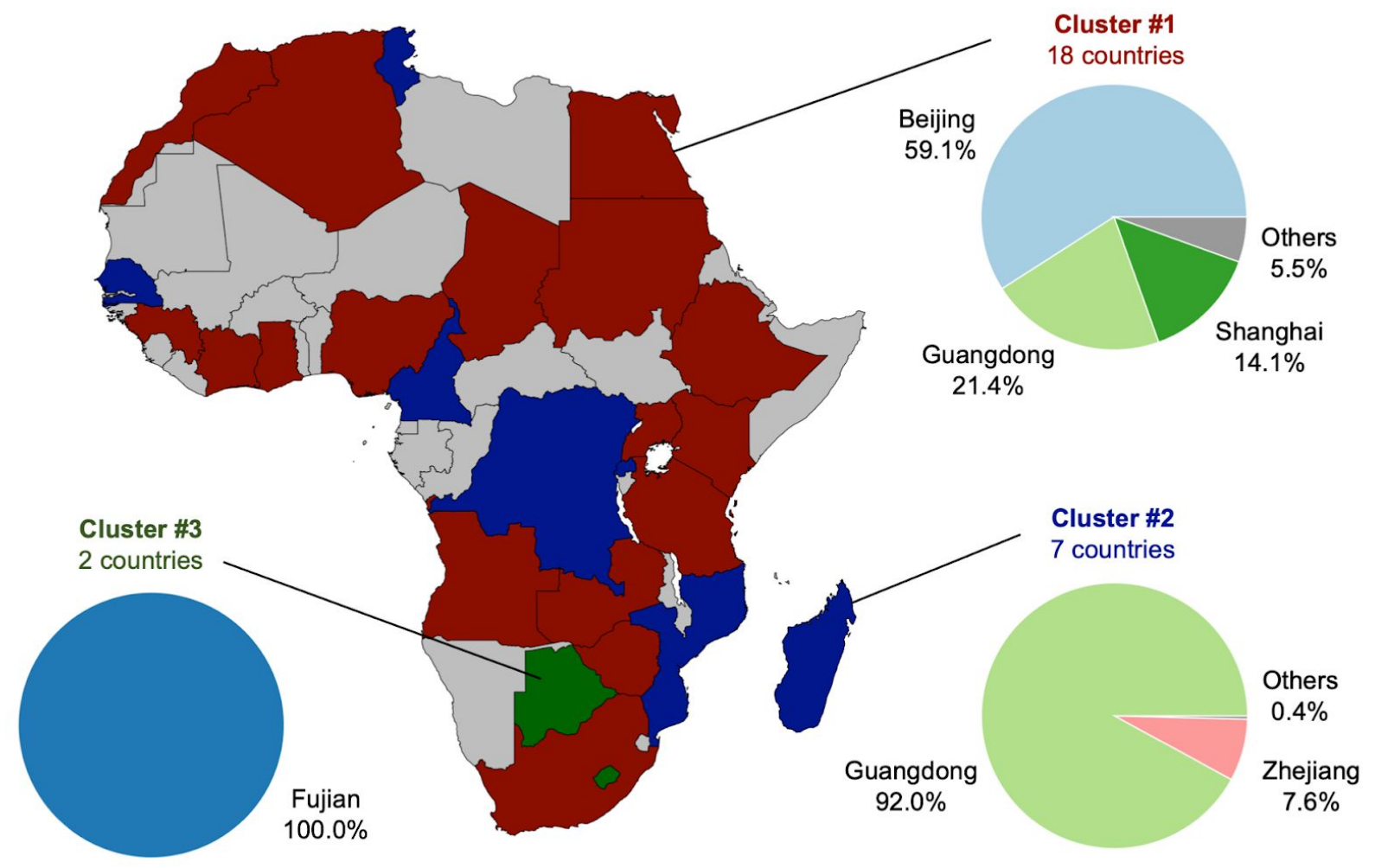

Figure 4. Cluster of countries sharing similar risk of importation from specific Chinese provinces (pie charts). Cluster \#1 (red): Algeria, Angola, Chad, Egypt, Ethiopia, Ghana, Guinea, 
medRxiv preprint doi: https://doi.org/10.1101/2020.02.05.20020792; this version posted February 7, 2020. The copyright holder for this preprint (which was not certified by peer review) is the author/funder, who has granted medRxiv a license to display the preprint in perpetuity.

It is made available under a CC-BY-ND 4.0 International license .

Ivory Coast, Kenya, Morocco, Nigeria, South Africa, Sudan, Tanzania, Uganda, Zambia, Zimbabwe. Cluster \#2 (blue): Cameroon, Democratic Republic of the Congo, MadagascarMozambique, Rwanda, Senegal andTunisia. Cluster \#3 (green): Botswana and Lesotho. Countries in grey were estimated to have a negligible risk of entry at the time of analysis.

\section{Discussion}

Early detection of 2019-nCoV coronavirus importation and prevention of onward transmission are crucial challenges to all countries at risk of introduction from areas with active transmission in China. Seven countries in Asia, Europe, and North America have already reported secondary spread following importation. Secondary spread potentially occurring in countries with weaker health systems represents a major public health concern.

Here we show that the risk of introduction to African countries is highly heterogeneous, with Egypt, Algeria, South Africa, Ethiopia and Nigeria estimated to be at highest risk. We also identified that part of this heterogeneity in Africa depended on the distribution of cases within Chinese provinces. Shifts in local and widespread transmission in Beijing, Guangdong and Fujiian provinces could have profound implications for risk in Africa. For example, a significantly higher incidence in Guangdong than in other provinces would have a stronger impact on the importation risk of countries of cluster \#2 than in countries from the other clusters. Also, flight bans put in place by some African airlines' companies serving China [18] may alter the risk in the future. However, the main transporters continue to fly from China to Africa via their hubs in Africa or Middle East (e.g. Ethiopian Airlines, the largest carrier in Africa, today operating almost half of the flights from Africa to China [19]). While certain provinces contribute the largest to the risk of specific clusters of countries, enhanced surveillance at the airports should consider that importation may however still occur from those Chinese provinces that appear to have a lower probability in our estimations.

Algeria, Ethiopia, South Africa, Nigeria were part of the 13 top priority countries identified by $\mathrm{WHO}$, based on their direct links and volume of travel to China [4]. Egypt, which was estimated here to be at highest risk, was not part of that list, although Cairo was identified as the African airport with the highest passenger volume from the affected areas [9]. Few other discrepancies were observed (Morocco and Angola were estimated to be at moderate risk but did not appear 
medRxiv preprint doi: https://doi.org/10.1101/2020.02.05.20020792; this version posted February 7, 2020. The copyright holder for this preprint (which was not certified by peer review) is the author/funder, who has granted medRxiv a license to display the preprint in perpetuity.

It is made available under a CC-BY-ND 4.0 International license .

in the 13 top priority list) that may be explained by different risk estimation approaches. In our assessment, we accounted for the distribution of incidence within China and the volume of travel from China with the passenger network. This strongly impacts the spatial pattern in the risk of introduction. Yet, our data does not allow distinguishing between travel for tourism or business. Contrary to Europe, where the majority of cases so far were Chinese tourists, it may be expected that cases in Africa will be more business related, given the strong commercial links between African countries and China leading to frequent trips between the two continents.

Countries at the highest risk of importation, based on current epidemic situation in China, had moderate to high capacity scores. These may however correspond to different contributions to the mean SPAR indicators, reflecting different aspects of a country's functional capacity. For example, South Africa had the maximum score for the laboratory capacity (100), but a low score in risk communication (20). Conversely, Nigeria had a fairly low score in the laboratory capacity (27) and the maximum score in the IHR coordination capacity (100). Conversely, countries with the lowest SPAR capacity score had moderate (Kenya, Tanzania, Ghana) to low introduction risk. The evaluation of additional factors (demographic, socio-economic, political) included in the IDVI that may influence the overall potential impact of an unfolding epidemic identifies several countries that had a significant importation risk with a low to medium IDVI, such as Nigeria, Ethiopia, Egypt and Algeria. The risk of importation from other points of entry, such as for example sea ports was not evaluated here.

Our results should be interpreted in relative terms. The overall SPAR score and IDVI of African countries is linked to their overall wealth, and are generally significantly lower than in many high-income countries, where the overall resource for detection, prevention and control are generally higher (SPAR ranging from 51 to 99 with a mean $=84.2$ and IDVI from 78 to 97 , with a mean $=88.3$ in OECD countries). Comparatively, China has a SPAR score of 93 and an IDVI of 63.

African countries have recently strengthened their preparedness against 2019-nCoV importations $[3,4,20]$. Many countries improved airport surveillance and implemented temperature screening at ports of entry, including high-risk countries according to our analysis South Africa [21], Ethiopia [22], and Nigeria [23], which also conducts interviews to passengers arriving from China. Overall recommendations to avoid travels to China have been issued. 
medRxiv preprint doi: https://doi.org/10.1101/2020.02.05.20020792; this version posted February 7, 2020. The copyright holder for this preprint (which was not certified by peer review) is the author/funder, who has granted medRxiv a license to display the preprint in perpetuity.

It is made available under a CC-BY-ND 4.0 International license .

Communication campaigns have been intensified following WHO guidelines to provide information to health professionals and the general public, often with $24 \mathrm{~h}$ dedicated hotlines, as in the case of Senegal [3].

Some countries remain however ill-equipped. Some lack the diagnostic for rapid testing for the virus, and, if cases are imported, tests will need to be performed abroad. This may critically increase the delay from identification of suspect cases to their confirmation and isolation, with an impact on possible disease transmission. WHO is currently supporting countries to improve their diagnostic capacity, previously limited to only two referral laboratories in the African region [4], and now extended also to Nigeria [24]. Also, resources to set up quarantine rooms for suspected cases at airports and hospitals, or to trace contacts of confirmed cases, as recommended by $\mathrm{WHO}$, may be scarce. Countries may not have the same capacity to manage repatriations of nationals from the province of Hubei in China, as done by resource-rich countries, because of limited resources for quarantine and isolation. The epidemic in China highlights the rapid saturation of the hospital capacity if the outbreak is not contained. Increasing the number of available beds and supplies in resource-limited countries is critical in preparation to possible local transmission following importation. Crisis management plans should be ready in each African country.

Our findings help informing urgent prioritization for intensified support for preparedness and response in specific countries in Africa found to be at high risk and with relatively low capacity to manage the health emergency.

\section{Acknowledgments}

This study was partially supported by the ANR project DATAREDUX (ANR-19-CE46-0008-03) to VC; the EU grant MOOD (H2020-874850) to MG, CP, MK, VC; Branco Weiss Fellowship to MK. We thank Rajesh Sreedharan for kind inputs on the use of IHR data, and REACTing (https://reacting.inserm.fr/) for useful discussions.

\section{References}

1. World Health Organization (WHO) Emergency Committee. Statement on the second meeting of the International Health Regulations (2005) Emergency Committee regarding the outbreak of 
medRxiv preprint doi: https://doi.org/10.1101/2020.02.05.20020792; this version posted February 7, 2020. The copyright holder for this preprint (which was not certified by peer review) is the author/funder, who has granted medRxiv a license to display the preprint in perpetuity.

It is made available under a CC-BY-ND 4.0 International license .

novel coronavirus (2019-nCoV). Geneva:WHO; 30 January 2020. Available from:

https://www.who.int/news-room/detail/30-01-2020-statement-on-the-second-meeting-of-the-inter national-health-regulations-(2005)-emergency-committee-regarding-the-outbreak-of-novel-coron avirus-(2019-ncov)

2. European Centre for Disease Prevention and Control (ECDC) Geographical distribution of 2019-nCov cases globally. Situation update 1 February 13:00 CET. Available at: https://www.ecdc.europa.eu/en/geographical-distribution-2019-ncov-cases

3. Le Monde. Coronavirus : l'Afrique en état d'alerte. 28 January 2020. Available at: https://www.lemonde.fr/afrique/article/2020/01/28/coronavirus-l-afrique-sur-ses-gardes_602753 8_3212.html

4. World Health Organization, Regional Office for Africa. WHO ramps up preparedness for novel coronavirus in the African region. 31 January 2020. Available at:

https://www.afro.who.int/news/who-ramps-preparedness-novel-coronavirus-african-region

5. Pullano G, Pinotti F, Valdano E, Boëlle P-Y, Poletto C, Colizza V. Novel coronavirus (2019-nCoV) early-stage importation risk to Europe, January 2020. Eurosurveillance. 2020;25:2000057.

6. Bogoch II, Watts A, Thomas-Bachli A, Huber C, Kraemer MUG, Khan K. Pneumonia of Unknown Etiology in Wuhan, China: Potential for International Spread Via Commercial Air Travel. J Travel Med. doi:10.1093/jtm/taaa008.

7. Wu JT, Leung K, Leung GM. Nowcasting and forecasting the potential domestic and international spread of the 2019-nCoV outbreak originating in Wuhan, China: a modelling study. The Lancet. 2020;0. doi:10.1016/S0140-6736(20)30260-9.

8. Chinazzi et al. Preliminary assessment of the International Spreading Risk Associated with the 2019 novel Coronavirus (2019-nCoV) outbreak in Wuhan City. Available at: https://www.mobs-lab.org/uploads/6/7/8/7/6787877/wuhan_novel_coronavirus_6_.pdf

9. Lai S, Bogoch II, Watts A, Khan K, Li Z, Tatem A. Preliminary risk analysis of 2019 novel coronavirus spread within and beyond China. Available at:

https://www.worldpop.org/resources/docs/china/WorldPop-coronavirus-spread-risk-analysis-v125Jan.pdf 
10. World Health Organization. International Health Regulations (2005): State Party self-assessment annual reporting tool. Geneva: World Health Organization; 2018. https://apps.who.int/iris/handle/10665/272432.

11. EpiRisk. Available at: https://epirisk.net/

12. 2018年民航机场生产统计公报 (in Chinese). Civil Aviation Administration of China. 2019-03-05. Available at: http://www.caac.gov.cn/XXGK/XXGK/TJSJ/201903/P020190305338562571372.xls?COLLCC=3 $782305670 \&$

13. Xu B, Gutierrez B, Hill S, Scarpino S, Loskill A, Wu J, et al. Epidemiological Data from the nCoV-2019 Outbreak: Early Descriptions from Publicly Available Data. 2020. Available at: https://github.com/beoutbreakprepared/nCoV2019

14. City Population. China: provinces and major cities. Available at:

http://www.citypopulation.de/en/china/cities/

15. Manning CD, Schütze $H$. Foundations of statistical natural language processing. Cambridge, Mass: MIT Press; 1999.

16. WHO Electronic State Parties Self-Assessment Annual Reporting Tool. Available at : https://extranet.who.int/e-spar

17. Moore, M., Gelfeld, B., Okunogbe, A., Paul, C., Gelfeld, B., 2016. Identifying future disease hot spots: infectious disease vulnerability index. RAND, Santa Monica, Calif. Available at: https://www.rand.org/pubs/research_reports/RR1605.html

18. Jeune Afrique. Un Boeing de la Royal Air Maroc (illustration). Royal Air Maroc, RwandAir, Kenya Airways,... six des huit compagnies aériennes africaines qui desservent la Chine, en proie à une épidémie de coronavirus, ont décidé de suspendre leurs liaisons. Ethiopian Airlines et Air Algérie ont choisi de maintenir leurs vols. 01 February 2020. Available at: https://www.jeuneafrique.com/889706/economie/coronavirus-lafrique-met-la-chine-en-quarantai ne/

19. Zhou, Y. Quartz Africa. Available at: https://qz.com/africa/1675287/china-toafrica-fights-jumped-630-in-the-past-nine-years/ 
medRxiv preprint doi: https://doi.org/10.1101/2020.02.05.20020792; this version posted February 7, 2020. The copyright holder for this preprint (which was not certified by peer review) is the author/funder, who has granted medRxiv a license to display the preprint in perpetuity.

It is made available under a CC-BY-ND 4.0 International license .

20. Nkengasong, J. China's response to a novel coronavirus stands in stark contrast to the 2002 SARS outbreak response. Nat Med (2020). https://doi.org/10.1038/s41591-020-0771-1

21. Independent Online South Africa. 1 February 2020. Concerns that the deadly coronavirus may hit South Africa. Available at:

https://www.iol.co.za/saturday-star/news/concerns-that-the-deadly-coronavirus-may-hit-south-afr ica-41867192

22. Capital Ethiopia. Screening for coronavirus begins at Bole International Airport. 27 January 2020. Available at:

https://www.capitalethiopia.com/capital/screening-for-coronavirus-begins-at-bole-international-ai rport/

23. Nigeria Centre for Disease Control. 3rd February 2020| PUBLIC HEALTH ADVISORY TO NIGERIANS ON NOVEL CORONAVIRUS (\#3). Available at:

https://www.ncdc.gov.ng/news/222/3rd-february-2020\%7C-public-health-advisory-to-nigerians-o n-novel-coronavirus-\%28\%233\%29

24. Nigeria Centre for Disease Control. The Nigeria Centre for Disease Control has successfully validated capacity to test for the novel \#coronavirus in \#Nigeria at our National Reference Laboratory (NRL). 3 February 2020. Available at:

https://twitter.com/NCDCgov/status/1224306344330780672 


\section{Appendix}

\section{Risk of case importation}

The risk of importation of 2019-nCoV cases in a country outside China, $\alpha$, from a city in China $i$, is based on:

- the travel flux from $i, n_{i}$;

- the cumulated incidence in $i, e_{i}$ (assumed to be homogeneous within each province);

- the probability of traveling from $i$ to $\alpha$, conditioned on traveling internationally from $i, A_{i \alpha}($ by construction, $\left.\sum_{\alpha} A_{i \alpha}=1\right)$.

We define risk flow from $i$ to $\alpha$ as the matrix

$$
r_{i \alpha}=\frac{e_{i} n_{i} A_{i \alpha}}{\sum_{j} e_{j} n_{j}} .
$$

The risk of case importation to $\alpha$ from whatever origin in China is then

$$
R_{\alpha}=\sum_{i} r_{i \alpha}
$$

This risk is normalized so that $\sum_{\alpha} R_{\alpha}=1$.

\section{Exposure analysis}

For each African country, $\alpha$, we define the exposure vector, $v^{(\alpha)}$, whose entry $v_{i}^{(\alpha)}$ encodes the contribution of city $i$ in China to the importation risk $R_{\alpha}$ :

$$
v_{i}^{(\alpha)}=\frac{r_{i, \alpha}}{R_{\alpha}}
$$

By construction these entries sum to one, $\sum_{i} v_{i}^{(\alpha)}=1$. Therefore, we can use entropy-related metrics to quantify the similarity between the exposure patterns of two different destination countries, $\alpha$ and $\beta$. Specifically, once defined the entropy of $v^{(\alpha)}$ as

$$
S\left(v^{(\alpha)}\right)=-\sum_{i} v_{i}^{(\alpha)} \log \log v_{i}^{(\alpha)}
$$

we used the Jensen-Shannon divergence between the two vectors, $v^{(\alpha)}$, and $v^{(\beta)}$, defined as

$$
\Delta_{\alpha \beta}=S\left(\frac{v^{(\alpha)}+v^{(\beta)}}{2}\right)-\frac{S\left(v^{(\alpha)}\right)+S\left(v^{(\beta)}\right)}{2},
$$

We then apply the complete linkage agglomerative clustering procedure to identify clusters of countries with similar exposure patterns. 